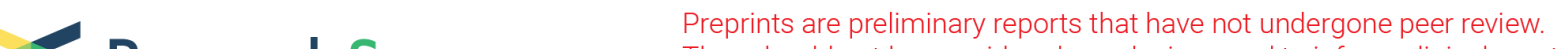 Research Square They should not be considered conclusive, used to inform clinical practice, or referenced by the media as validated information.
}

\section{AnchoisFert: A New Organic Fertilizer from Fish Processing Waste for Sustainable Agriculture}

\section{Adele Muscolo}

Università Mediterranea di Reggio Calabria https://orcid.org/0000-0002-0439-1614

Francesco Mauriello

Università Mediterranea di Reggio Calabria https://orcid.org/0000-0002-6002-2151

Francesca Marra

Università Mediterranea di Reggio Calabria

Paolo Salvatore Calabrò

Università Mediterranea di Reggio Calabria https://orcid.org/0000-0002-2153-9457

Mariateresa Russo

Università Mediterranea di Reggio Calabria https://orcid.org/0000-0002-5159-588X

Rosaria Ciriminna

Istituto per lo Studio dei Materiali Nanostrutturati, CNR https://orcid.org/0000-0001-6596-1572

Mario Pagliaro ( $\square$ mario.pagliaro@cnr.it)

Istituto per lo Studio dei Materiali Nanostrutturati, CNR https://orcid.org/0000-0002-5096-329X

\section{Research Article}

Keywords: Fish waste, organic fertilizer, red onion, anchovy, circular economy, AnchoisFert

Posted Date: January 27th, 2022

DOI: https://doi.org/10.21203/rs.3.rs-1017059/v2

License: (c) (1) This work is licensed under a Creative Commons Attribution 4.0 International License.

Read Full License

Version of Record: A version of this preprint was published at Global Challenges on March $2 \mathrm{nd}, 2022$. See the published version at https://doi.org/10.1002/gch2.202100141. 


\title{
Article
}

\section{AnchoisFert: A New Organic Fertilizer from Fish Processing Waste for Sustainable Agriculture}

\author{
Adele Muscolo, ${ }^{*}$ Francesco Mauriello, ${ }^{2}$ Francesco Marra, ${ }^{1}$ Paolo Salvatore Calabrò, ${ }^{2}$ \\ Mariateresa Russo, ${ }^{1}$ Rosaria Ciriminna, ${ }^{3}$ Mario Pagliaro ${ }^{3 *}$ \\ 'Dipartimento di Agraria, Università Mediterranea di Reggio Calabria, Feo di Vito, 89124 Reggio Calabria (Italy) \\ 2Dipartimento di Ingegneria Civile, Energia, Ambiente e Materiali, Università Mediterranea di Reggio Calabria, via Graziella, Feo di Vito, 89122 \\ Reggio Calabria (Italy) \\ ${ }^{3}$ Istituto per lo Studio dei Materiali Nanostrutturati, CNR, via U. La Malfa 153, 90146 Palermo (Italy) \\ *Correspondence: muscolo@unirc.it, mario.pagliaro@cnr.it
}

\section{SUMMARY}

The "AnchoisFert" solid residue comprised of milled anchovy leftovers after fish oil extraction with biobased limonene is a powerful organic fertilizer. Employed to promote the growth of Tropea's red onion (Allium cepa), the fertilizer turns out to largely superior to commonly used organic (manure) and chemical (NPK) fertilizers. Rich in proteins, organic carbon, flavonoids, magnesium, potassium, phosphate and sulphate, and devoid of antibiotics and antibiotic resistance genes, the new organic fertilizer can replace both conventional organic and inorganic fertilizers. The discovery closes the fishing material cycle for one of the most fished species across the seas opening the route to a new class of organic fertilizers of exceptional performance derived from abundant biowaste via a low-cost, environmentally-friendly circular economy process.

Keywords: Fish waste; organic fertilizer; anchovy; circular economy; AnchoisFert.

\section{INTRODUCTION}

Rich in essential proteins and essential polyunsaturated ("omega-3") lipids, vitamin D, iodine, iron, calcium, zinc and other micronutrients, fish, shrimp and other marine species are fundamental components of human diets across virtually all world's countries. ${ }^{[1]}$ Between 1961 and 2017 the world's population went from less than 3.1 billion to 7.6 billion people. In the same period, per capita food fish consumption rose from $9.0 \mathrm{~kg}$ (live weight equivalent) to $20.3 \mathrm{~kg}{ }^{[2]}$ Not surprisingly, in 2018 the global fish production reached the staggering 179 million tonne threshold, 156 million of which used for human consumption. ${ }^{[2]}$ This remarkable growth was made possible also by aquaculture which expanded fish availability to regions and countries with limited access to the cultured species.

Unfortunately, the aforementioned growth in seafood demand has been met also by the growth of overfishing. Recently, the share of stocks overfished was found to vary from $59 \%$ in the Mediterranean and Black Sea, to $>40 \%$ in the southwest, eastern and western central Atlantic, and southeast Pacific oceans. ${ }^{[3]}$ Besides fish populations and fisheries, overfishing affects marine ecosystems functioning in general. ${ }^{[4]}$

Efforts aimed at improving the overall (economic, social and environmental) sustainability of fishing include the economic valorization of fish processing waste. About $25 \%$ of the global amount of the total fish capture every year is comprised of fish and shrimp tissue not suitable for consumption (bones, shell, intestine, fin, heads, tails and skin). ${ }^{[5]}$ This fish (and shrimp) processing waste is chiefly used as raw material for the production of fish oil and of 
fishmeal. However, only $25 \%$ of fish waste is currently converted into fishmeal products. Between 2018 and 2030, the proportion of total fishmeal obtained from fish waste has been estimated to modestly increase from $22 \%$ to $28 \%$ (and that of fish oil from $40 \%$ to $45 \%$ ). ${ }^{[2]}$

Depending on the fish species, selected fish processing companies (e.g. tuna processing companies) sell fish biowaste to pet food producers. Most fish processing companies, however, face negative costs to get rid of fish processing waste. In Italy, for example, in 2020 the typical tariff paid by a fish processing company for biowaste disposal was $€ 5 / \mathrm{kg}{ }^{[6]}$

Plentiful research has been devoted in the last two decades to develop methods to convert these wastes into high value products such as fish oil, fish hydrolysate, collagen, chitin, chitosan and hydroxyapatite. ${ }^{[7]}$ In this context, a circular economy process for the extraction of fish oil from anchovy leftovers using biobased limonene as sole extraction solvent was introduced in Sicily in 2019. ${ }^{[8]}$ After extraction, the agrosolvent derived from the citrus fruit processing industry is nearly entirely recovered, whereas the new oil rich of PUFAs and oleic acid in their natural triglyceride form, and vitamin $D$ in vitamin $D_{3}$ most bioavailable form, ${ }^{\left[{ }^{[9]}\right.}$ is ready for producing new dietary supplements and likely new therapeutic treatments (see below).

Though generally using highly refined lipids in diethyl ester form as active ingredients, ${ }^{[10]}$ omega-3 lipids are widely consumed worldwide as dietary supplements due the unbalanced diet in most world's countries which has created what Winkler has called "the most hidden hunger" ${ }^{111]}$ namely that of docosahexaenoic acid (DHA) and eicosapentaenoic acid (EPA) present in fish oils in triglyceride form.

Anchovies are the most fished species in the world. Stocks are threatened in many countries. For example, in Spain's and France's Bay of Biscay the anchovy fishing was forbidden between July 2005 and early 2010 when it reopened with a total allowable catch of only 7,000 tonnes. In 2019 , however, the catch jumped to nearly 27,000 metric tons, with the biomass of all spawning-age anchovies in 2020 being the highest since the Biscay anchovy surveys began in $1987 .{ }^{[12]}$ The recovery of the anchovy population was caused by the closure of the fishery for five years. ${ }^{[13]}$

Anchovies fished in the Biscay Bay or in the Mediterranean sea are used to produce renowned anchovy fillets. About $50 \%$ of the whole fish is converted into fillet. The leftovers are disposed of as biowaste at high economic costs. Clearly, providing fisheries with extra revenues originating from the valorisation of anchovy fillet leftovers would reduce the risk of overfishing, especially when producing high added value bioproducts from said biowaste.

One such product is the new "AnchoisOil" fish oil extracted from anchovy leftovers with biobased $d$-limonene only (Scheme 1).

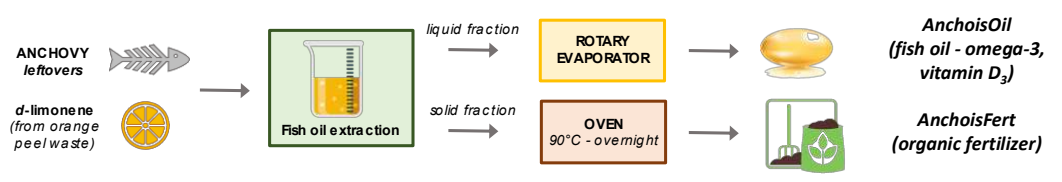

Scheme 1. Overall upgrading process of anchovy fillet leftovers converted into AnchoisOil and AnchoisFert.

Rich in oleic acid, DHA and EPA in natural triglyceride form, the oil contains also plentiful vitamin $D$ in its most bioavailable form (vitamin $D_{3}$ ), and a carotenoid imparting the orange colour whose nature and amount will be shortly reported. Encapsulated in silica, the new oil acts as a promising antiproliferative agent against lung cancer cells. ${ }^{[14]}$ 
The oily fraction extracted with limonene, however, comprises only 10 weight percent of the of the anchovy leftover. Aware of the rich protein, mineral and carbon content of the extraction residue, we therefore investigated its employment as organic fertilizer.

Generally commercialized in the form of nitrates, phosphates and potassium salt powder mixtures, chemical fertilizers are widely used across the world to maximize crop yields. Their use, however, pose significant environmental and health problems due to accumulation of heavy metals, inorganic acids and organic pollutants in soil ${ }^{[15]}$ and groundwater ${ }^{[16]}$ and depletion of organic carbon in agricultural soils.

Furthermore, the cost of chemical fertilizers is high (and continuously growing) making their use economically not viable for many farmers. In brief, the replacement of chemical nutrients with organic fertilizers is highly desirable. The main problem with the latter fertilizers, however, is the poor performance as their effect on crop yield is often slow and variable. ${ }^{[17]}$ Highly effective and economically viable organic fertilizers would be in high demand. Along with strengthened membership of farmer organizations and better policy measurements, ${ }^{[18]}$ their development might convince farmers to replace chemical with organic fertilization.

In the following we report the discovery that the solid residue of anchovy fillet leftovers extracted with biobased limonene, named herein "AnchoisFert", is a powerful fertilizer capable to promote the growth of Tropea's red onion (Allium cepa) significantly better than commonly used chemical and organic fertilizers. The discovery closes the fishing material cycle for anchovy fishing and dramatically increases the sustainability of both anchovy fishing and agriculture.

\section{RESULTS AND DISCUSSION}

Anchovy leftovers were chemically and physically characterized with respect to the main parameters of relevance to agriculture, namely $\mathrm{pH}$, electrical conductivity, main ions, carbon, nitrogen, total flavonoid and phenol content. Data in Table 1 are expressed in units perg of leftover dried weight (DW).

The anchovy leftover residue of the extraction is mildly acidic ( $\mathrm{pH}$ is 6.27) and has poor electrical conductivity $\left(5.9 \mu \mathrm{S} \mathrm{cm}^{-1}\right)$. The residue has a very high content of both carbon $(40 \%)$ and nitrogen (12\%) that, along with the large amount of valued mineral nutrients, in particular calcium $\left(35.2 \mathrm{mg} \mathrm{g}^{-1}\right)$ and sulphate $\left(16.2 \mathrm{mg} \mathrm{g}^{-1}\right)$, but also magnesium $\left(6.7 \mathrm{mg} \mathrm{g}^{-1}\right)$, potassium $\left(5.5 \mathrm{mg} \mathrm{g}^{-1}\right)$ and phosphate $\left(5.6 \mathrm{mg} \mathrm{g}^{-1}\right)$, is very promising in light of its employment as fertilizer.

Additionally, these wastes contain also bioactive compounds such as phenols $(8507 \mu \mathrm{g} / \mathrm{g}$ total phenol content expressed as tannic acid equivalent, $T A E$, per g DW) and flavonoids $(1868 \mu \mathrm{g} / \mathrm{g}$ total flavonoid content expressed as quercetin equivalent, $\mathrm{OE}$, per $\mathrm{g} \mathrm{DW}$ ), with well-known antioxidant activity. 
Table 1. Main chemical and physical parameters of anchovy leftovers after oil extraction with limonene

\begin{tabular}{|c|c|}
\hline Chemical parameter & Value \\
\hline Total solids (TS) & $20.1 \%$ \\
\hline Volatile solids (VS) & $66.7 \%$ \\
\hline$C$ & $40 \%$ \\
\hline $\mathrm{N}$ & $12 \%$ \\
\hline $\mathrm{C} / \mathrm{N}$ & $3 \cdot 3$ \\
\hline Total phenol content & $8507 \mu \mathrm{g}$ TAE/mg \\
\hline Total flavonoids & $1868 \mu \mathrm{g} \mathrm{QE} / \mathrm{mg}$ \\
\hline $\mathrm{pH}$ & 6.27 \\
\hline Electrical conductivity & $5.945 \mu \mathrm{S} \mathrm{cm}^{-1}$ \\
\hline $\mathrm{Ca}^{2+}$ & $35.2 \mathrm{mg} \mathrm{g}^{-1}$ \\
\hline $\mathrm{K}^{+}$ & $5.5 \mathrm{mg} \mathrm{g}^{-1}$ \\
\hline $\mathrm{Mg}^{2+}$ & $6.7 \mathrm{mg} \mathrm{g}^{-1}$ \\
\hline $\mathrm{SO}_{4}{ }^{2-}$ & $16.2 \mathrm{mg} \mathrm{g}^{-1}$ \\
\hline $\mathrm{PO}_{4}^{3-}$ & $5.6 \mathrm{mg} \mathrm{g}^{-1}$ \\
\hline Limonene & $0.140 \mathrm{mg} \mathrm{g}^{-1}$ \\
\hline
\end{tabular}

Table 2 lists the chemical parameters of non-fertilized soil (CTR), chemically-fertilized (NPK), and organically-fertilized soils with horse manure (HM) and AnchoisFert (AF), analyzed after onion harvesting ( 3 months). Data are expressed in units per $\mathrm{g}$ of dried soil (DS).

The anchovy-based fertilizer limited the increase of the electrical conductivity $\left(357 \mu \mathrm{S} \mathrm{cm}^{-1}\right)$. The soil treated with it had the highest total phenol $\left(550 \mathrm{\mu g} \mathrm{TAE} \mathrm{g}^{-1}\right)$, carbon $(3.59 \%)$, and nitrogen (0.26\%) content. Likely due to specific inhibition of dehydrogenase enzyme by phenols contained in AnchoisFert, as it happens with shikimate dehydrogenase inhibited by several polyphenols, ${ }^{[19]}$ the dehydrogenase activity (DHA) of soil fertilized with AF was the lowest $\left(1.48 \mu \mathrm{g} \mathrm{TPF}^{-1} \mathrm{~h}^{-1}\right)$ amid all studied soils. Indeed, the fact that most phenolics and flavonoids contained in AnchoisFert are actually beneficial to soil microbial activity was clearly shown by total microbial activity measured using fluorescein diacetate (FDA) hydrolysis which returned the highest value $\left(32.6 \mu \mathrm{g}\right.$ fluorescein $\left.\mathrm{g}^{-1}\right)$ for the soil fertilized with AF. 
For comparison, the soil fertilized with NPK chemical fertilizer and HM organic fertilizer respectively gave 21.8 and $16.9 \mu \mathrm{g}$ fluorescein $\mathrm{g}^{-1} \mathrm{FDA}$ values. Furthermore, soil organic matter (OM) reached the highest value $(6.19 \%)$ in soil fertilized with AnchoisFert. We briefly remind that $\mathrm{OM}$ is an indicator of soil quality directly linked to the soil ability to work as nutrient sink and promote biological activity affecting the supply of energy for microbial growth and enzyme production. ${ }^{[20]}$

Table 2. Chemical and biochemical parameters of non-fertilized (CTR), chemically-fertilized (NPK), and organically-fertilized (HM and AF) soils after onion harvesting

\begin{tabular}{|c|c|c|c|c|c|c|c|c|c|c|}
\hline Fertilizer & $\begin{array}{c}\mathrm{pH} \\
\left(\mathrm{H}_{2} \mathrm{O}\right)\end{array}$ & $\begin{array}{l}\mathrm{pH} \\
(\mathrm{KCl})\end{array}$ & $\begin{array}{c}\text { EC } \\
\left(\mu \mathrm{S} \mathrm{cm}^{-1}\right)\end{array}$ & $\begin{array}{c}\text { TPC } \\
\left(\mu \mathrm{TAE} \mathrm{g}^{-1}\right)\end{array}$ & $\begin{array}{c}\text { DHA } \\
\left(\begin{array}{c}\mu \mathrm{g} \text { TPF g } \\
\left.h^{-1}\right)\end{array}\right.\end{array}$ & $\begin{array}{c}\text { FDA } \\
\left(\mu \mathrm{g} \text { fluorescein } \mathrm{g}^{-1}\right)\end{array}$ & $\begin{array}{l}\text { C } \\
(\%)\end{array}$ & $\begin{array}{l}\mathrm{N} \\
(\%)\end{array}$ & $\begin{array}{l}\text { OM } \\
(\%)\end{array}$ & $C / N$ \\
\hline CTR & $8.06^{a}$ & $6.98^{\mathrm{a}}$ & $436^{a}$ & $351^{c}$ & $1.66^{\mathrm{b}}$ & $17.6^{c}$ & $3.54^{\mathrm{a}}$ & $0.22^{b}$ & $6.11^{\mathrm{a}}$ & $16^{a}$ \\
\hline NPK & $8.14^{a}$ & $6.99^{a}$ & $43^{8^{a}}$ & $407^{b}$ & $2.08^{a}$ & $21.8^{\mathrm{b}}$ & $3.21^{b}$ & $0.20^{b}$ & $5 \cdot 54^{b}$ & $16^{a}$ \\
\hline $\mathrm{HM}$ & $7.97^{\mathrm{a}}$ & $6.98^{\mathrm{a}}$ & $391^{b}$ & $380^{b}$ & $1.68^{b}$ & $16.9^{c}$ & $2.52^{c}$ & $0.23^{\mathrm{b}}$ & $4.34^{c}$ & $11^{\mathrm{c}}$ \\
\hline $\mathrm{AF}$ & $8.19^{\mathrm{a}}$ & $6.89^{a}$ & $357^{c}$ & $50^{a}$ & $1.48^{c}$ & $32.6^{\mathrm{a}}$ & $3.59^{\mathrm{a}}$ & $0.26^{a}$ & $6.19^{\mathrm{a}}$ & $14^{b}$ \\
\hline
\end{tabular}

${ }^{a}$ Data expressed as mean of three replicates. Different letters indicate significant differences at $p<0.05$

The analysis of cations and anions in non-fertilized (CTR), chemically-fertilized (NPK) and organically-fertilized ( $\mathrm{HM}$ and $\mathrm{AF}$ ) soils analyzed after onion harvesting (3 months) presented significant differences (Table 3 , data expressed in units per g of DS).

In general, treatment with $\mathrm{AF}$ resulted in the largest increases with respect to all cations measured. A 16 -fold increase (from $0.45 \times 10^{-2}$ to $7.2 \times 10^{-2} \mathrm{mg} \mathrm{g}^{-1}$ ) was measured for ammonium in soils fertilized with AnchoisFert, followed by a 13.5 -fold increase in the presence of horse manure, which is rich in urea and ammonia. A $35 \%$ increase in potassium was observed in soils treated with both organic fertilizers (AF and HM). This increase was higher $(35 \%$ vs. $28 \%)$ than that measured in the presence of the NPK chemical fertilizer containing nearly pure potassium nitrate. The 3 -fold increase in magnesium in soil fertilized with the new fertilizer was particularly significant, and higher than the 2-fold increase in the presence of the NPK fertilizer. Finally, a 1.5-fold increase in calcium was observed for soil fertilized with AF, followed by a 1.17 increase for the soil fertilized with HM.

Getting to anions, it is important to notice that the amount of fluoride remained unvaried to very low level ( $0.01 \mathrm{mg} \mathrm{g}^{-1}$ ) for bulbs grown in non-treated soil and soil fertilized with AF, whereas it even decreased by $40 \%$ when going from the control soil to soil fertilized with horse manure (from $1 \times 10^{-2}$ to $0.6 \times 10^{-2} \mathrm{mg} / \mathrm{g}$ ). Similar good results were measured for nitrite whose content remained unvaried to $7 \times 10^{-2} \mathrm{mg} / \mathrm{g}$ in all bulbs, independent of fertilization with chemical or organic fertilizers.

A significant increase in bulbs from plants grown in organically fertilized soils was observed for both chloride and nitrate ions. In detail, chloride went from $0.14 \mathrm{mg} / \mathrm{g}$ to 1.2 and 0.7 $\mathrm{mg} / \mathrm{g}$ upon treatment with $\mathrm{AF}$ and $\mathrm{HM}$, respectively. The 5.5 -fold increase in nitrate (from 0.09 to $0.5 \mathrm{mg} / \mathrm{g}$ ) was the largest for bulbs grown in plants in soils treated with HM, followed by the 4.4 -fold increase for bulbs grown in plants in the presence of AF. 
Table 3. Cations and anions in non-fertilized (CTR), chemically-fertilized (NPK), and organically-fertilized (HM and AF) soils after onion harvesting

\begin{tabular}{|c|c|c|c|c|}
\hline Cation & $\begin{array}{c}\text { CTR } \\
\left(\mathrm{mg} \mathrm{g}^{-1}\right)\end{array}$ & $\begin{array}{c}\text { NPK } \\
\left(\mathrm{mg} \mathrm{g}^{-1}\right)\end{array}$ & $\begin{array}{c}\mathrm{HM} \\
\left(\mathrm{mg} \mathrm{g}^{-1}\right)\end{array}$ & $\begin{array}{c}\mathrm{AF} \\
\left(\mathrm{mg} \mathrm{g}^{-1}\right)\end{array}$ \\
\hline $\mathrm{NH}_{4}^{+}$ & $0.0045 \pm 0.02^{a}$ & $0.059 \pm 0.01^{a}$ & $0.061 \pm 0.01^{a}$ & $0.072 \pm 0.02^{\mathrm{a}}$ \\
\hline $\mathrm{K}^{+}$ & $1.4 \pm 0.1^{b}$ & $1.8 \pm 0.2^{\mathrm{a}}$ & $1.9 \pm 0.3^{a}$ & $1.9 \pm 0.2^{\mathrm{a}}$ \\
\hline $\mathrm{Mg}^{2+}$ & $0.11 \pm 0.07^{c}$ & $0.22 \pm 0.06^{b}$ & $0.21 \pm 0.05^{b}$ & $0.33 \pm 0.04^{a}$ \\
\hline $\mathrm{Ca}^{2+}$ & $0.29 \pm 0.09^{a}$ & $0.21 \pm 0.1^{\mathrm{a}}$ & $0.34 \pm 0.1^{\mathrm{a}}$ & $0.44 \pm 0.7^{\mathrm{a}}$ \\
\hline Anion & $\begin{array}{c}\text { CTR } \\
\left(\mathrm{mg} \mathrm{g}^{-1}\right)\end{array}$ & $\begin{array}{c}\text { NPK } \\
\left(\mathrm{mg} \mathrm{g}^{-1}\right)\end{array}$ & $\begin{array}{c}\mathrm{HM} \\
\left(\mathrm{mg} \mathrm{g}^{-1}\right)\end{array}$ & $\begin{array}{c}\mathrm{AF} \\
\left(\mathrm{mg} \mathrm{g}^{-1}\right)\end{array}$ \\
\hline $\mathrm{F}^{-}$ & $0.01 \pm 0.01^{a}$ & $0.03 \pm 0.01^{a}$ & $0.006 \pm 0.0^{b}$ & $0.01 \pm 0.01^{a}$ \\
\hline $\mathrm{Cl}^{-}$ & $0.14 \pm 0.01^{d}$ & $0.4 \pm 0.07^{c}$ & $0.7 \pm 0.01^{b}$ & $1.2 \pm 0.1^{\mathrm{a}}$ \\
\hline $\mathrm{Br}$ & $\mathrm{Nd}$ & $0.03^{\mathrm{a}}$ & $0.03^{a}$ & $0.03^{\mathrm{a}}$ \\
\hline $\mathrm{NO}_{3}^{-}$ & $0.09 \pm 0.01^{b}$ & $0.3 \pm 0.02^{\mathrm{a}}$ & $0.5 \pm 0.02^{\mathrm{a}}$ & $0.4 \pm 0.02^{\mathrm{a}}$ \\
\hline $\mathrm{NO}_{2}^{-}$ & $0.07 \pm 0.01^{\mathrm{ca}}$ & $0.07 \pm 0.02^{a}$ & $0.07 \pm 0.01^{a}$ & $0.07 \pm 0.01^{a}$ \\
\hline $\mathrm{SO}_{4}{ }^{2--}$ & $0.1 \pm 0.01^{c}$ & $3.5 \pm 1.2^{\mathrm{ab}}$ & $2 \pm 0.3^{b}$ & $4.1 \pm 2^{\mathrm{a}}$ \\
\hline
\end{tabular}

${ }^{a}$ Data expressed as mean of three replicates. Different letters indicate significant differences at $p<0.05$

These increases, once again, were larger than the 3.3-fold increase measured in bulbs from plants grown in soil treated with the NPK fertilizer rich in concentrated nitrate ions. Finally, a remarkable 41-fold increase in sulphate ion was observed for bulbs grown in soil fertilized with AnchoisFert, followed by a 35 -fold increase for bulbs from soil fertilized with the chemical fertilizer NPK containing abundant sulphate anions.

The plant growth parameters of red onion grown in pots for three months (maturation time) with chemical fertilizer NPK (20:10:10; $1.2 \mathrm{~g} /$ pot), horse manure (13 g/pot), and AnchoisFert (1.60 g/pot) showed significant differences (Table 4). 
Table 4. Growth parameters of red onion grown for three months in non-fertilized (CTR), chemically (NPK), horse manure (HM), and AnchoisFert (AF) fertilizer

\begin{tabular}{lcccc}
\hline Parameter & CTR & NPK & HM & AF \\
\hline Bulb weight (g) & $102 \pm 2^{\mathrm{b}}$ & $82 \pm 5^{\mathrm{c}}$ & $101 \pm 4^{\mathrm{b}}$ & $136 \pm 5^{\mathrm{a}}$ \\
\hline Bulb diameter $(\mathrm{cm})$ & $4 \pm 1^{\mathrm{b}}$ & $3 \pm 1^{\mathrm{b}}$ & $4 \pm 0.7^{\mathrm{b}}$ & $7 \pm 1^{\mathrm{a}}$ \\
\hline Leaf length (cm) & $46 \pm 3^{\mathrm{a}}$ & $42 \pm 2^{\mathrm{a}}$ & $42 \pm 2^{\mathrm{a}}$ & $46 \pm 2^{\mathrm{a}}$ \\
\hline Average plant height $(\mathrm{cm})$ & $64 \pm 2^{\mathrm{a}}$ & $55 \pm 3^{\mathrm{b}}$ & $63 \pm 3^{\mathrm{a}}$ & $68 \pm 2^{\mathrm{a}}$ \\
\hline
\end{tabular}

${ }^{a}$ Data expressed as mean \pm standard error. Different letters indicate significant differences at $p<0.05$

With the exception of the leaf length that remained unvaried to $46 \mathrm{~cm}$, once again fertilization with AnchoisFert afforded the best results. Also, the other vegetation parameter, the plant height, remained nearly unvaried increasing by just $4 \mathrm{~cm}$ when going from plant grown in non-fertilized soil to plant grown in the presence of AF. The fruit parameter, however, dramatically changed. For plants grown in soil fertilized with AnchoisFert, the bulb weight increased by $33 \%$, from 102 to $136 \mathrm{~g}$, whereas the diameter rose by $75 \%$, from 4 to $7 \mathrm{~cm}$ (Figure 1).

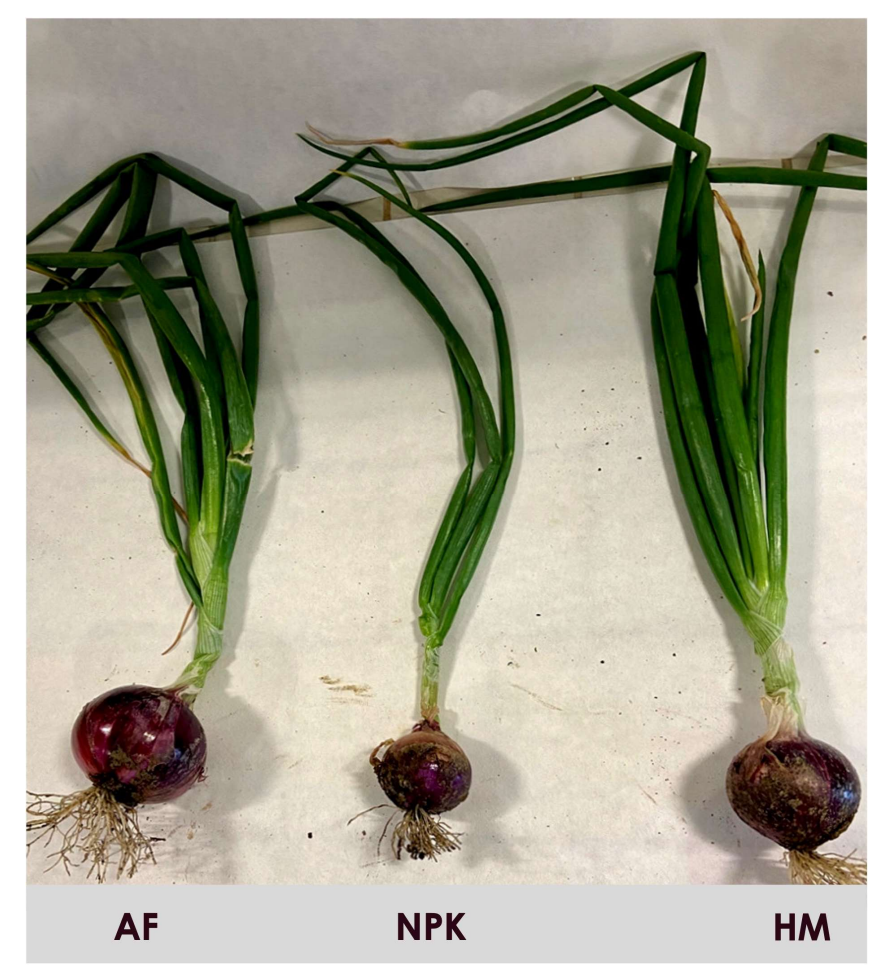

Figure 1. Tropea's red onion plant grown in soil fertilized with AnchoisFert (left), NPK (center) and horse manure (right).

Treatment with the other organic fertilizer, $\mathrm{HM}$, did not produce changes neither in the weight nor in the diameter of the onion bulb. Fertilization of the soil with the NPK chemical fertilizer was detrimental for the fruit whose weight and diameter diminished by $19.6 \%$ and $25 \%$, respectively. 
The analysis of cations and anions in red onion bulbs grown in pots for three months (maturation time) with the aforementioned different fertilizers in the same amounts mentioned above revealed once again significant differences (Table $\mathbf{5}$, results expressed in $\left.\mathrm{mg} \mathrm{g}^{-1} \mathrm{DW}\right)$.

Table 5. Cations and anions detected in red onion bulbs grown in pots for three months (maturation time) with chemical (NPK), horse manure (HM), and AnchoisFert (AF) fertilizer

\begin{tabular}{|c|c|c|c|c|}
\hline Cation & $\begin{array}{c}\text { CTR } \\
\left(\mathrm{mg} \mathrm{g}^{-1}\right)\end{array}$ & $\begin{array}{c}\text { NPK } \\
\left(\mathrm{mg} \mathrm{g}^{-1}\right)\end{array}$ & $\begin{array}{c}\mathrm{HM} \\
\left(\mathrm{mg} \mathrm{g}^{-1}\right)\end{array}$ & $\begin{array}{c}\text { AF } \\
\left(\mathrm{mg} \mathrm{g}^{-1}\right)\end{array}$ \\
\hline $\mathrm{NH}_{4}^{+}$ & $8.7 \pm 0.5^{d}$ & $10.3 \pm 0.7^{c}$ & $31 \pm 2^{a}$ & $20 \pm 3^{b}$ \\
\hline $\mathrm{K}^{+}$ & $100 \pm 4^{a}$ & $96 \pm 2^{a}$ & $103 \pm 3^{a}$ & $102 \pm 2^{a}$ \\
\hline $\mathrm{Mg}^{2+}$ & $4.6 \pm 0.9^{b}$ & $4.9 \pm 0.8^{b}$ & $7 \cdot 9 \pm 1^{a}$ & $7 \cdot 5 \pm 2^{a}$ \\
\hline $\mathrm{Ca}^{2+}$ & $8.6 \pm 1.2$ & $10 \pm 1.5^{b}$ & $16 \pm 2^{a}$ & $15 \pm 1^{a}$ \\
\hline Anion & $\begin{array}{c}\text { CTR } \\
\left(\mathrm{mg} \mathrm{g}^{-1}\right)\end{array}$ & $\begin{array}{c}\text { NPK } \\
\left(\mathrm{mg} \mathrm{g}^{-1}\right)\end{array}$ & $\begin{array}{c}\mathrm{HM} \\
\left(\mathrm{mg} \mathrm{g}^{-1}\right)\end{array}$ & $\begin{array}{c}\text { AF } \\
\left(\mathrm{mg} \mathrm{g}^{-1}\right)\end{array}$ \\
\hline $\mathrm{F}^{-}$ & $0.47 \pm 0.02^{a}$ & $0.34 \pm 0.04^{b}$ & $0.16 \pm 0.03^{c}$ & $0.29 \pm 0.02^{b}$ \\
\hline $\mathrm{Cl}^{-}$ & $4 \pm 0.5^{b}$ & $16.4 \pm 2^{\mathrm{a}}$ & $3.8 \pm 0.9^{b}$ & $19 \cdot 4 \pm 2^{a}$ \\
\hline $\mathrm{Br}$ & n.a. & $0.8 \pm 0.3^{a}$ & n.a. & $0.7 \pm 0.4^{a}$ \\
\hline $\mathrm{NO}_{3}^{-}$ & $1.2 \pm 0.5^{a}$ & $0.7 \pm 0.2^{a}$ & $1.1 \pm 0.6^{a}$ & $0.7 \pm 0.3^{a}$ \\
\hline $\mathrm{NO}_{2}^{-}$ & $5 \cdot 9 \pm 1^{a}$ & $4.7 \pm 0.8^{a}$ & $3.9 \pm 0.9^{a}$ & $3.7 \pm 0.7^{a}$ \\
\hline $\mathrm{SO}_{4}^{2--}$ & $1.9 \pm 0.3^{b}$ & $35 \pm 1.2^{a}$ & $2 \pm 0.3^{b}$ & $41 \pm 2^{a}$ \\
\hline Malate & $2.8 \pm 0.6^{a b}$ & $3.6 \pm 0.7^{a}$ & $2.1 \pm 0.1^{b}$ & $2.4 \pm 0.2^{b}$ \\
\hline
\end{tabular}

aData expressed as mean of three replicates. Different letters indicate significant differences at $p<0.05$

Pointing to significant bioavailability of nitrogen present in horse manure chiefly as urea and ammonia, and in proteins in AnchoisFert, the amount of ammonium in red onion bulbs significantly increased, from 8.17 to $31 \mathrm{mg} / \mathrm{g}$ and to $20 \mathrm{mg} / \mathrm{g}$ when going from non-fertilized soil to soils fertilized with $\mathrm{HM}$ and $\mathrm{AF}$, respectively.

The amount of potassium slightly increased by $2 \%$ and $3 \%$ for onions growing in soils fertilized with the aforementioned organic fertilizers, but remarkably decreased by $4 \%$ for onions grown in soil fertilized with the NPK chemical fertilizer containing nearly pure potassium nitrate. Remarkably, the amounts of highly health-beneficial $\mathrm{Mg}^{2+}$ and $\mathrm{Ca}^{2+}$ increased by $63 \%$ and $74 \%$ for onions grown in soil fertilized with the new marine fertilizer, and even more in the presence of horse manure ( $72 \%$ and $86 \%$, respectively). The amount 
of $\mathrm{Mg}^{2+}$ remained nearly unvaried (from 4.6 to $4.9 \mathrm{mg} / \mathrm{g}$ ) for onions grown in the presence of the NPK chemical fertilizer, whereas the amount of $\mathrm{Ca}^{2+}$ increased by $16 \%$.

Remarkably, the amount of toxic fluoride and nitrate ions decreased in all fertilized bulbs compared to control, noticeably more for fluoride in bulbs grown in soils fertilized with HM (from 0.47 to $0.16 \mathrm{mg} / \mathrm{g}$ ) and with AF (from 0.47 to $0.29 \mathrm{mg} / \mathrm{g}$ ). The decrease was more limited in the case of NPK fertilized bulbs (from 0.47 to $0.34 \mathrm{mg} / \mathrm{g}$ ). The amount of nitrate went from 1.2 to $0.7 \mathrm{mg} / \mathrm{g}$ for both AF and NPK fertilized bulbs. Pointing once again to large bioavailability of nitrogen in horse manure fertilizer, the decrease was negligible (from 1.2 to $1.1 \mathrm{mg} / \mathrm{g}$ ) for HM fertilized bulbs.

Chloride increased in NPK fertilized bulbs from 4 to $16.4 \mathrm{mg} / \mathrm{g}$, and even more for bulbs fertilized by the new marine fertilizer AnchoisFert when the concentration of chloride in bulbs reached $19.4 \mathrm{mg} / \mathrm{g}$ (a 4.85 -fold increase). Bromide was detected only in NPK (o.8 $\mathrm{mg} / \mathrm{g})$ and $\mathrm{AF}(0.7 \mathrm{mg} / \mathrm{g})$ treated bulbs, likely due to the presence of bromide impurities in the NPK chemical fertilizer and of native sea bromide in fish biowaste. Nitrate and phosphate did not show significant differences between control and treatments. Sulphate, however, increased remarkably in NPK and AF treated bulbs, respectively going from 1.9 to $35 \mathrm{mg} / \mathrm{g}$ (a 18.4 increase) and from 1.9 to $41 \mathrm{mg} / \mathrm{g}$ (a 22 -fold increase). Malate slightly decreased in organically fertilized bulbs and increased from 2.8 to $3.6 \mathrm{mg} / \mathrm{g}$ in NPK treated bulbs $(+28 \%)$.

Finally, results in Table 6 (expressed per unit mass of dried weight of red onion) show that fertilization barely affected the protein, carbohydrate and fiber content in red onion bulbs grown in pots for three months (maturation time) with different fertilizers: NPK 20:10:10 (1.2 g/pot), horse manure (13 g/pot), and AnchoisFert ( $1.60 \mathrm{~g} / \mathrm{pot}$ ).

Table 6. Total phenolic, flavonoid, protein and carbohydrate content, vitamin A and fiber in red onion bulbs grown in pots for three months in non-fertilized (CTR), chemically (NPK), horse manure (HM), and AnchoisFert (AF) fertilized soils

\begin{tabular}{lcccc}
\hline Parameter & CTR & NPK & HM & AF \\
\hline Total phenolic content $(\mu \mathrm{g} \mathrm{TAE} / \mathrm{g})$ & $14040 \pm 15^{\mathrm{d}}$ & $17280 \pm 33^{\mathrm{c}}$ & $18930 \pm 16^{\mathrm{b}}$ & $23370 \pm 27^{\mathrm{a}}$ \\
\hline Total flavonoid content $(\mu \mathrm{g} \mathrm{QE} / \mathrm{g})$ & $2601 \pm 34^{\mathrm{d}}$ & $3305 \pm 28^{\mathrm{c}}$ & $3866 \pm 31^{\mathrm{b}}$ & $4914 \pm 29 \mathrm{a}$ \\
& & & & \\
\hline Vitamin A $(\mu \mathrm{g} / \mathrm{g})$ & $0.17 \pm 0.02^{\mathrm{c}}$ & $0.39 \pm 0.03^{\mathrm{a}}$ & $0.25 \pm 0.01^{\mathrm{b}}$ & $0.26 \pm 0.03^{\mathrm{b}}$ \\
\hline Total protein $(\mathrm{mg} / \mathrm{g})$ & & & & \\
\hline & $96 \pm 2^{\mathrm{b}}$ & $105 \pm 2^{\mathrm{a}}$ & $101 \pm 4^{\mathrm{a}}$ & $97 \pm 3^{\mathrm{a}}$ \\
\hline aData expressed as mean \pm standard error. Different letters indicate significant differences at $\mathrm{p}<0.05$ &
\end{tabular}

${ }^{a}$ Data expressed as mean \pm standard error. Different letters indicate significant differences at $p<0.05$

The total phenolic content (TPC) and the total flavonoid content (TFC), however, significantly increased in fertilized red onion bulbs with respect to control, particularly in the case of organically fertilized onion bulbs. Once again, the greatest increases were observed in onions fertilized with AnchoisFert, followed by HM. In detail, the TPC went from 14040 to $23370 \mu \mathrm{g} \mathrm{TAE} / \mathrm{g}$, for AF treated bulbs, a 66\% increase, whereas the TFC increased even more (by 89\%) going from 2601 to $4914 \mu \mathrm{g} \mathrm{OE} / \mathrm{g}$. Fertilization with HM resulted in a $35 \%$ increase in TPC and a $48 \%$ in TFC. Fertilization with the NPK chemical fertilizer led to the lowest increase in TPC and TFC with respect to control, namely 23 and 27 per cent. Only vitamin A (retinol being one of the main forms of vitamin A) reached the highest value $\left(0.39 \mathrm{mg} \mathrm{g}^{-1}\right)$ when soil was fertilized with the NPK chemical fertilizer.

\section{CONCLUSIONS}

Named "AnchoisFert", the solid residue comprised of milled anchovy leftovers after fish oil extraction with biobased limonene to obtain a new fish oil rich vitamin $D_{3}$ and oleic acid 
and omega-3 lipids in natural triglyceride form, ${ }^{[8,9]}$ is an exceptional organic fertilizer. Employed to promote the growth of Tropea's red onion (Allium cepa), the fertilizer turned out to largely superior to commonly used organic (manure) and chemical (NPK) fertilizers.

Farmers looking for economically viable organic fertilizers capable to afford higher yields of valued horticulture crops find in AnchoisFert a soil and plant nutrient practically able to afford red onions of $33 \%$ higher bulb weight and $75 \%$ larger bulb diameter. Consumers in their turns would find on the marketplace Tropea's red onions, already known for their health benefits due to enhanced content of flavonols and anthocyanins, ${ }^{[2]}$ with $66 \%$ higher total phenolic and $75 \%$ higher total flavonoid content. The new organic fertilizer is rich in proteins, organic carbon, flavonoids, magnesium, potassium, phosphate and sulphate and can be used to promote the healthy growth of a variety of crops, replacing inorganic and organic fertilizers.

These findings close the anchovy fishing material cycle, dramatically improving the sustainability of both fishing and agriculture thanks to the use as extraction solvent of biobased limonene solvent derived from waste orange peel in a closed-loop production cycle. The process indeed shifts fish oil and fish-based fertilizer production from blue fish to blue fish waste, ${ }^{[22]}$ opening the route to the introduction of a new class of organic fertilizers of exceptional performance based on fish biowaste upgraded using a low-cost, environmentally-friendly circular process.

The newly extracted 'AnchoisOil' fish oil will be commercialized in the omega-3 marine lipids marketplace, whereas the dried fertilizer can be directly sold to farmers for use in valued horticulture. In this way, the residues of the anchovy fillet production are completely converted into two highly valued bioproducts thanks to a zero-waste circular production process in which the solvent, recovered after extraction of the AnchoisOil and the concomitant production of AnchoisFert, is made available for subsequent production cycles. ${ }^{[8]}$

Using this circular economy process no prolonged (several weeks long) composting of fish waste mediated by bacteria in composting plants is required to produce a nutrient-rich fertilizer. ${ }^{[23]}$ No expensive extraction equipment (as it happens with supercritical carbon dioxide), enzymes or toxic organic solvents derived from petroleum are required for converting fish biowaste in two valued functional bioproducts in high demand.

It is also relevant, in light of forthcoming practical utilization of AnchoisFert as organic fertilizer, that the use of AnchoiFert anchovy biowaste in place of manure will not increase the abundance (and number) of antibiotic resistance genes in fertilized soil and crops as it happens when using manure containing large amounts of antibiotics and antibiotic resistance genes. ${ }^{[24]}$

Finally, the small amount of nicely scented fragrance and powerful antibacterial citrus limonene ${ }^{[25]}$ residual in AnchoisFert limits the formation of bad odours typical of untreated fish biowaste due to trimethylamine rapid accumulation during storage. ${ }^{\left[{ }^{[6]}\right.}$ We are currently investigating the use of AnchoisFert in the fertilization of other valued horticulture crops. This study demonstrated the proof of concept directly on a valued horticulture (Tropea's red onion) generating revenues exceeding $€ 25$ million (for 25,000 tonnes production) in $2017 \cdot .^{[27]}$

\section{EXPERIMENTAL METHODS}

4.1 Elemental composition, $\mathrm{pH}$ and electrical conductivity

Total and volatile solids and $\mathrm{pH}$ were evaluated according to standard methods. ${ }^{[28]}$ Carbon and nitrogen content $(\mathrm{C} / \mathrm{N})$ was measured using a total organic carbon analyzer TOC-LCSH (Shimadzu, Kyoto, Japan).

The analysis of the residual limonene in anchovy leftovers after fish oil extraction and solvent removal was carried out according to a previously reported procedure. ${ }^{[29]} \mathrm{A}$ sample of the solid ( $0.3 \mathrm{~g}$ ) was stirred with $3 \mathrm{~mL}$ of a toluene solution (as an internal standard) in cyclohexane (0.1 M) for $6 \mathrm{~h}$, after which the suspension was filtered and a liquid aliquot injected into a offline GC-FID Agilent 689oN gas chromatograph (Agilent, Santa Clara, CA, USA) equipped with a CP-WAX ${ }_{52} \mathrm{CB}$ column $(60 \mathrm{~m}$, i.d. $0.53 \mathrm{~mm}$ ) also purchased from Agilent. 
Electrical conductivity was determined using a HI5522 (Hanna Instruments, Woonsocket, RI, USA) conductivity meter. A 1:5 anchovy leftovers/water suspension (using distilled water) was mechanically shaken for $1 \mathrm{~h}$ at $15 \mathrm{rpm}$ to dissolve the water-soluble salts after which we measurement the conductivity.

4.2 Fertilization experiment

In all experiments, we used a sandy-loam ( $11.85 \%$ clay. $23.21 \%$ silt. and $64.94 \%$ sand) soil as defined in the World Reference Base. ${ }^{\left[{ }^{0}\right]}$ Each experiment was performed using pots of 30 $\mathrm{cm}$ diameter containing $9 \mathrm{~kg}$ of soil with a $\mathrm{pH}$ of 8.87 and $1.81 \%$ of organic matter. Pots were amended with AnchoisFert at the concentration of $1.60 \mathrm{~g}$ on the basis of its carbon content (40\%). Non-fertilized soil (CTR), organically fertilized soil with horse manure (Violmet Italy, Pisa ) and chemically fertilized soil with NPK (Agricoltura Italia, Taranto) were used as controls. The experiments were performed in triplicates in greenhouse as previously reported. ${ }^{\left[{ }^{3}\right]}$

Pots were regularly watered to ensure that water content was maintained at $70 \%$ of field capacity. At the end of the experiments ( 90 days after treatments) the differently treated soils (three replicates) were air-dried and sieved $(<2 \mathrm{~mm}$ ) prior to the chemical analysis. Soil samples for the biochemical determination (microbial biomass and enzyme activities) were stored in the refrigerator at $4^{\circ} \mathrm{C}$ for up to $24 \mathrm{~h}$ until processing.

4:3 Soil analysis

Dry matter content of un-amended and amended soils was determined at $105^{\circ} \mathrm{C}$ until the mass loss of the sample during $24 \mathrm{~h}$ was lower than $0.5 \%$ of its weight. Electrical conductivity was measured with a Hl5522 conductivity meter (Hanna Instruments, Woonsocket, $\mathrm{RI}, \mathrm{USA}$ ). Samples were suspended in distilled water (1:5 residue/water) and mechanically shaken at $15 \mathrm{rpm}$ for $1 \mathrm{~h}$ to dissolve soluble salts. The $\mathrm{pH}$ was measured in distilled water (soil:water ratio 1:2.5) with a HI 2210 glass electrode (Hanna Instruments, Woonsocket, RI, USA).

Organic carbon and total nitrogen (TN) were assessed with conventional methods, namely the dichromate oxidation and Kjeldahl methods, respectively. Microbial biomass carbon was determined in field moist samples (equivalent to $20 \mathrm{~g} \mathrm{DW}$ ) by Vance's extraction method. ${ }^{\left[{ }^{2}\right]}$ Soil extracts of both fumigated and unfumigated samples were filtered and analysed for soluble organic carbon. MBC was estimated on the basis of the differences between the organic $C$ extracted from the fumigated soil and that from the unfumigated soil. An extraction efficiency coefficient of 0.38 was used to convert soluble $\mathrm{C}$ into biomass C. ${ }^{[32]}$

Water-soluble phenols were extracted in triplicate as reported by Kaminsky and Muller. ${ }^{[33]}$ Total water-soluble phenols (monomeric and polyphenols) were determined by using the Folin-Ciocalteau reagent. Tannic acid was used as a standard and the concentration of water-soluble phenolic compounds expressed as microgram of tannic acid/gram of dry soil $\left(\mu \mathrm{g}\right.$ TAE g $\left.{ }^{-1} \mathrm{DS}\right)$. Fluorescein diacetate hydrolase (FDA) was determined according to the method of Adam and Duncan. ${ }^{[34]}$ Dehydrogenase (DHA) activity was determined by the method of von Mersi and Schinner. ${ }^{[35]}$

Cations and anions were detected by ion chromatography using a Dionex ICS-1100 ion chromotograph (Thermo Fisher Scientific, Waltham, MA, USA). For anion analysis, $0.5 \mathrm{~g}$ of dried material were stirred for 20 min using $50 \mathrm{ml}$ of anion solution $\left(\mathrm{Na}_{2} \mathrm{CO}_{3} / \mathrm{NaHCO}_{3} 3.5\right.$ $\mathrm{mM}$ ), filtering the extract through a Whatman 1 filter paper prior to the chromatographic analysis. For the cation analysis, $1 \mathrm{~g}$ of dry material was reduced to ash at $550^{\circ} \mathrm{C}$ for $5-6 \mathrm{~h}$ in a porcelain capsule. The ash was then mineralized for $30 \mathrm{~min}$ at $100^{\circ} \mathrm{C}$ using concentrated ( $1 \mathrm{M}) \mathrm{HCl}$. The resulting solution was filtered through a Whatman 1 filter paper and analyzed by ion chromatography using $20 \mathrm{mM}$ meta-sulfonic acid as eluent.

4:4 Plant analysis

The fertilizers (fish waste, horse manure, NPK) were tested on a comparative basis on Allium cepa $L$. (red onion). Each time, the experiment was terminated at bulb maturity as characterized by neck softening and reduced solution uptake. Bulb diameters were measured using a calliper. Leaf and root length were measured with a meter. Plants were harvested and separated into shoots, bulbs, and roots. After weighing the fresh plant and 
its parts, the latter were dried at $70{ }^{\circ} \mathrm{C}$ in a oven. Dry weights were determined and plant materials were ground to pass a 20-mesh sieve. Antioxidant compounds and antioxidant activities in the differently fertilized onion bulbs were measured at the end of each growth cycle.

4.5 Assessment of phenolic compounds in bulb

Total phenol content was detected by the Folin-Ciocalteu assay adapted to assess monomeric phenols and polyphenols red onion. ${ }^{\left[{ }^{[6]}\right]}$ The absorbance of each sample was recorded at $760 \mathrm{~nm}$ using a UV-180o high-resolution spectrophotometer (Shimadzu, Kyoto, Japan). A calibration curve was constructed using gallic acid and results were expressed as micrograms of tannic acid per $\mathrm{g}$ DW. Total flavonoids in the extracts were detected measuring the absorbance was measured at $430 \mathrm{~nm}$. Flavonoid content was calculated from a calibration curve of quercetin and expressed as micrograms of quercetin per $\mathrm{g} D W$.

4.6 Determination of antioxidant activities in plants

The antioxidant activity against DPPH radical (2.2-diphenyl-1-picryl-hydrazyl-hydrate) was determined according to a spectrophomometric method previously reported. ${ }^{[37]}$ The DPPH concentration in the cuvette was chosen to give absorbance values of $\sim 1.0$. Changes in absorbance of the violet solution at $517 \mathrm{~nm}$ were recorded after $30 \mathrm{~min}$ incubation at $37^{\circ} \mathrm{C}$. The inhibition I(\%) of radical-scavenging activity was calculated as in Eq.1

$I(\%)=\left[\left(A_{\circ}-A_{s}\right) / A_{0}\right] \times 100$

where $A_{o}$ is the absorbance of the control, and $A_{s}$ is the absorbance of the sample following 30 min incubation.

The 2,2'-azinobis(3-ethylbenzothiazoline-6-sulfonic acid) diammonium salt (ABTS) radical cation decolorization assay was conducted measuring the absorbance at $734 \mathrm{~nm}$ according to a published method. ${ }^{\left[{ }^{88]}\right.}$ The inhibition I(\%) of radical-scavenging activity was calculated from Eq.1 where $A_{o}$ is the absorbance of the control and $A_{S}$ is the absorbance of the sample after 4 min incubation. Results are expressed as $\mu \mathrm{mol} \mathrm{L} \mathrm{L}^{-1} \mathrm{TE}$ using a Trolox (1-50 $\mu \mathrm{mol} \mathrm{\textrm {L } ^ { - 1 }}$ ) calibration curve. The oxygen radical absorbance capacity (ORAC-fluorescein) assay was carried out according to a published method. ${ }^{[39]}$ An aliquot $(20 \mu \mathrm{L})$ of the extract was added to a small sample $(120 \mu \mathrm{L})$ of fresh fluorescein solution $\left(117 \mathrm{nmol} \mathrm{L}^{-1}\right)$. After an incubation time of $15 \mathrm{~min}$ at $37^{\circ} \mathrm{C}$, a sample $(60 \mu \mathrm{L})$ of freshly prepared $\mathrm{AAPH}$ solution $\left(40 \mathrm{mmol} \mathrm{L}^{-1}\right)$ was added and fluorescence $\left(\lambda_{\mathrm{ex}} 485 \mathrm{~nm}, \lambda_{\mathrm{em}} 520 \mathrm{~nm}\right.$ ) measured every $30 \mathrm{~s}$ for a $90 \mathrm{~min}$ overall analysis time. A blank sample using $20 \mu \mathrm{L}$ of methanol was also analyzed. The ORAC values derived from a Trolox $\left(10-100 \mu \mathrm{mol} \mathrm{L}^{-1}\right)$ calibration curve are expressed as equivalent of Trolox micromoles per $\mathrm{mg}$ fresh weight.

4.7 Statistical analysis

Analysis of variance was carried out for all the data sets. Significant difference tests were carried out to analyse the effects of fertilizers on each parameter measured. ANOVA and Ttest were carried out using the SPSS software for statistical analysis. ${ }^{[40]}$ Effects were considered significant at $p \leq 0.05$.

\section{ACKNOWLEDGMENTS}

We thank the Università degli Studi Mediterranea di Reggio Calabria for financial support.

\section{AUTHOR CONTRIBUTIONS}

Adele Muscolo, Rosaria Ciriminna: Conceptualization, Methodology, Supervision, Writing Review and Editing; Francesco Mauriello, Mario Pagliaro: Conceptualization, WritingOriginal Draft, Funding Acquisition; Maria Teresa Russo and Paolo S. Calabrò: Resource Acquisition, Methodology, Writing - Review and Editing; Francesco Marra: Experimental Investigation, Methodology.

\section{DECLARATION OF INTERESTS}

The authors declare no competing interests.

\section{Data availability}


All data reported in this study are freely available by contacting one of the corresponding Authors.

\section{REFERENCES}

[1]. T. Boujard, M. Jobling, Food Intake in Fish, Blackwell Science, Oxford: 2001.

[2] Food and Agriculture Organization of the United Nations, The State of World Fisheries and Aquaculture 2020, Rome: 2020. https://www.fao.org/publications/sofia/2020/en/ (accessed October 25, 2021).

[3] J. L. Blanchard, R. A. Watson, E. A. Fulton, R. S. Cottrell, K. L. Nash, A. BryndumBuchholz, M. Büchner, D. A. Carozza, W. W. L. Cheung, J. Elliott, L. N. K. Davidson, N. K. Dulvy, J. P. Dunne, T. D. Eddy, E. Galbraith, H. K. Lotze, O. Maury, C. Müller, D. P. Tittensor, S. Jennings, Nat. Ecol. Evol. 2017, 1, 1240-1249. https://doi.org/10.1038/s41559017-0258-8

[4] J. S. Link, R. A. Watson, Sci. Av. 2019, 5, eaavo474. https://dx.doi.org/10.1126\%2Fsciadv.aav0474

[5] I.S. Arvanitoyannis, A. Kassaveti, Int. J. Food Sci. 2008, 43, 726-745. https://doi.org/10.1111/j.1365-2621.2006.01513.

[6] Interreg Italia Malta, Bythos, New market evaluation report for fishmeal and fish feed from fish residues, February 2021. https://www.culturadelmare.it/bythos/wpcontent/uploads/D-5.2_Fish-feed-target-markets.pdf (accessed October 25, 2021).

[7] T. Maschmeyer, R. Luque, M. Selva, Chem. Soc. Rev. 2020, 49, 4527-4563. https://doi.org/10.1039/cgcs00653b

[8] R. Ciriminna, A. Scurria, G. Avellone, M. Pagliaro, ChemistrySelect 2019, 4, 5106-5109. https://doi.org/10.1002/slct.201900851

[9] A. Scurria, C. Lino, R. Pitonzo, M. Pagliaro, G. Avellone, R. Ciriminna, Chem. Data Coll. 2020, 25, 100311. https://doi.org/10.1016/j.cdc.2019.100311

[10] R. Ciriminna, F. Meneguzzo, R. Delisi, M. Pagliaro, Sustain. Chem. Pharm. 2017, 5, 5459. http://dx.doi.org/10.1016/j.scp.2017.03.001

[11] J.T. Winkler, World Rev. Nutr. Diet. 2018, 118, 123-130. https://doi.org/10.1159/000484645

[12] S. van Gilder Cooke, How a strategic fishery closure helped save Spain's beloved anchovy, oceana.org, April 2, 2020. https://oceana.org/blog/how-strategic-fishery-closurehelped-save-spain-beloved-anchovy (accessed October 25, 2021).

[13] J. Bueno-Pardo, P. Petitgas, S. Kay, M. Huret, ICES Mar. Sci. 2020, 77, 655-667. https://doi.org/10.1093/icesjms/fsz239

[14] C. Di Sano, C. D’Anna, A. Scurria, C. Lino, M. Pagliaro, R. Ciriminna, E. Pace, Nanomedicine 2021, 16, 2061-2074. https://doi.org/10.2217/nnm-2021-0202

[15] Y.-C. Bai, Y.-Y. Chang, M. Hussain, Bin Lu, J.-P. Zhang, X.-B. Song, X.-S. Lei, D. Pei, Microorganisms 2020, 8, 694. https://doi.org/10.3390/microorganisms8050694 
[16] A.L. Srivastav, Chemical fertilizers and pesticides: role in groundwater contamination In Agrochemicals Detection, Treatment and Remediation, M.N.V. Prasad, Ed., ButterworthHeinemann, Oxford: 2020; pp.143-159. https://doi.org/10.1016/b978-0-08-103017-2.000064

[17] A. Khaliq, M.K. Abbasi, T. Hussain, Bioresour. Technol. 2006, 97, 967-972. https://doi.org/10.1016/j.biortech.2005.05.002

[18] Y. Wang, Y. Zhu, S. Zhang, Y. Wang, J. Clean. Prod. 2018, 199, 882-890. https://doi.org/10.1016/j.jclepro.2018.07.222

[19] J. Peek, T. Shi, D. Christendat, J Biomol Screen. 2014, 19, 1090-1098. https://doi.org/10.1177/1087057114527127

[20] B. Wolf, G. Snyder, Sustainable Soils: The Place of Organic Matter in Sustaining Soils and their Productivity, Haworth Press, New York: 2003.

http://dx.doi.org/10.1017/S0014479704292055

[21] I. Tedesco, V. Carbone, C. Spagnuolo, P. Minasi, G.L. Russo, J. Agric. Food Chem. 2015, 63, 5229-5238. https://doi.org/10.1021/acs.jafc.5b01206

[22] R. Ciriminna, A. Scurria, A. S. Fabiano-Tixier, C. Lino, G. Avellone, F. Chemat, M. Pagliaro, ACS Omega 2019, 4, 15359-15363. https://doi.org/10.1021/acsomega. 9 bo1168

[23] S. Mohri, M. Kanauchi, Methods Mol Biol. 2019, 1887, 109-117. https://doi.org/10.1007/978-1-4939-8907-2_10

[24] F. Wang, W. Han, S. Chen, W. Dong, M. Qiao4, C. Hu, B. Liu, Front. Microbiol. 2020, 11, 62. https://doi.org/10.3389/fmicb.2020.00062

[25] R. Ciriminna, M. Lomelli, P. Demma Carà, J. Lopez-Sanchez, M. Pagliaro, Chem. Commun. 2014, 50, 15288-15296. http://dx.doi.org/10.1039/c4cc06147k

[26] A.M. Martin, Composting of seafood wastes In Maximising the Value of Marine ByProducts, F. Shahidi, Ed., Woodhead Publishing, Cambridge: 2007; pp. 486-515. https://doi.org/10.1533/9781845692087.3.486

[27] E. Di Girolamo, II successo della cipolla rossa di Tropea trascina le aziende che trasformano la regina dei prodotti Igp, ilvibonese.it, 25 January 2018. https://www.ilvibonese.it/economia-e-lavoro/9273-cipolla-rossa-successo-trascinaaziende-comparto/ (accessed October 25, 2021).

[28] E.W. Rice, R.B. Baird, A.D. Eaton, L.S. Clesceri, (Ed.s), Standard Methods for the Examination of Water and Wastewater, $22^{\text {nd }}$ Edition; American Public Health Association, Washington, DC: 2012.

[29] E. Paone, F. Fazzino, D.M. Pizzone, A. Scurria, M. Pagliaro, R. Ciriminna, P.S. Calabrò, Sustainability 2021, 13, 2428. https://doi.org/10.3390/su13052428

[30] FAO, Harmonized World Soil Database (version 1.0), Rome, Italy and IIASA, Laxenburg, Austria: 2008. https://www.fao.org/uploads/media/Harm-World-Soil-DBv7cv_1.pdf

[31] A. Muscolo, C. Mallamaci, G. Settineri, G. Calamarà, Agron. J. 2017, 109, 1900-1910. https://doi.org/10.2134/agronj2017.03.0143 
[32] E.D. Vance, P.C. Brookes, D.S. Jenkinson, Soil Biol. Biochem. 1987, 19, 703-707. https://doi.org/10.1016/0038-0717(87)90052-6

[33] R. Kaminsky, W.H. Muller, Soil Sci. 1977, 124, 205-210. https://journals.Iww.com/soilsci/Abstract/1977/10000/THE_EXTRACTION_OF_SOIL_PHYT OTOXINS_USING_A_NEUTRAL.3.aspx

[34] G. Adam, H. Duncan, Soil Biol. Biochem. 2001, 33, 943-951. https://doi.org/10.1016/s0038-0717(00)00244-3

[35] W. von Mersi, F. Schinner, Biol. Fertil. Soils 1991, 11, 216-220. https://doi.org/10.1007/bfo0335770

[36] A. Muscolo, T. Papalia, G. Settineri, C. Mallamaci, M.R. Panuccio, J. Sci. Food. Agric. 2020, 100, 785-793. https://doi.org/10.1002/jsfa.10086

[37] T. Papalia, D. Barreca, M.R. Panuccio, Int. J. Mol. Sci. 2017, 18, 660. https://doi.org/10.3390/ijms18030660

[38] R. Re, N. Pellegrini, A. Proteggente, A. Pannala, M. Yang, C. Rice-Evans, Free Radic. Biol. Med. 1999, 26, 1231-1237. https://doi.org/10.1016/S0891-5849(98)00315-3

[39] A. Dávalos, C. Gómez-Cordovés, B. Bartolomé, J. Agric. Food Chem. 2004, 52, 48-54. https://doi.org/10.1021/jf0305231

[40] IBM, IBM SPSS Statistics for Windows, Version 21.0, Armonk (NY): 2012. 